\title{
Evaluation of Physico-chemical Properties in Selected Branded Soaps
}

\author{
Sarfaraz Ahmed Mahesar, Razia Chohan and Syed Tufail Hussain Sherazi* \\ National Centre of Excellence in Analytical Chemistry, University of Sindh, Jamshoro-78060, Pakistan. \\ *Corresponding Author Email: tufail.sherazi@yahoo.com \\ Received 06 February 2019, Revised 06 November 2019, Accepted 10 November 2019
}

\begin{abstract}
Quality of soaps is directly related with their physicochemical properties. Generally, ranking of the soaps remains indistinct to consumers therefore there is strong need to assess the quality of soaps available in the market. In the present study, eighteen commercial soaps including fourteen toilet soaps and four baby soaps were evaluated for moisture content, $\mathrm{pH}$, total fatty matter, total alkali, free alkali, foam test and emulsification. Values of moisture content ranged between 5.40-15.12\%; pH 6.29-11.39; total fatty matter 59-91\%; total alkali $0.98-1.60 \%$ and free alkali $0.01-0.62 \%$. The emulsification was observed in all analyzed samples and the foam height was measured in the range between $2.3-8.5 \mathrm{~cm}$. Most of analyzed samples fall within the standard values recommended by International Standard Organization, but in few samples $\mathrm{pH}$, total alkali and free alkali were found to be higher than the recommended values.
\end{abstract}

Keywords: Toilet soaps, Baby soaps, Physicochemical parameters, Standard values

\section{Introduction}

The skin is the body's largest organ, acts as a physical barrier between the body and many atmospheric pollutants. When products such as soaps, shampoos and cosmetics are used on the skin, the ingredients in them come into direct contact with the skin [1]. Toiletries are primarily used to clean the body and maintain personal hygiene. These products fall into the fast-moving consumer group (FMCG) due to their high demand and how quickly they are consumed. This group includes bathing soaps in liquid and solid form [1]. Babylonians were making soaps around 2800 BC revealed evidence of ancient Babylon by an excavation [2]. There is a steady rise in the production of both toilet and laundry soap. Soap, is chemically a combination of $\mathrm{Na}+$ or $\mathrm{K}+$ ions and fatty acids. Over a hundred fatty acids are known to exist today. Out of these hundred and over, forty are known to occur widely [3]. Palm, neem coconut, tallow, palm kernel, cocoa butter, and ground pea nut fats and oils are suitable for traditional soaps manufacture process [4]. Soaps are gained from fats known as glycerides were the earliest surfactant. They formed esters by the propane-1,2,3-triol(glycerol), trihydric alcohol through long chain carboxylic acids (fatty acids). The glycerides are hydrolyzed by way of heating with sodium hydroxide solution to form soaps, propane-1,2,3-triole, the acids of the sodium salts through process of saponification $[5,6]$.

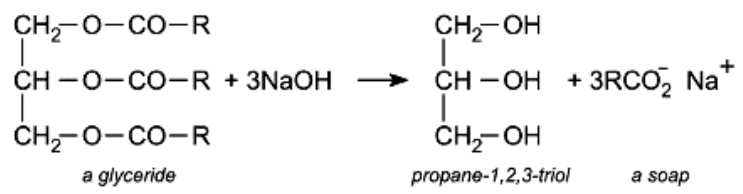

Types of oil/fat and alkali used for manufacturing of soaps greatly effect on the quality and physiochemical properties of the soaps. Sodium and potassium hydroxides are often used for the preparation of soaps with of pure or blend of vegetable oils or animal fats. Soaps of 
potassium are softer than the soaps of sodium [7, 8]. Recovery of soaps during manufacturing process depends on the level of the total fatty matter (TFM). The TFM is very important characteristic to describe the value of soap and it is always specified in commercial trading. Soaps are graded in terms of TFM. Level of TFM is also associated with hardness of soaps. The soaps with higher TFM gives more lather, lasts longer and more importantly cleans the skin in a better way and more gently [7]. The lipophilic part of soap which have a chemical nature the major role plays in determination the performance of soaps [9]. When used for cleaning, soaps allow insoluble particles to convert soluble in water and rinsed away. For example: when two or more drops of liquid soaps are added to the mixture, so it can be easily dissolves in the water otherwise it is difficult to soluble in water. The insoluble oil/fat molecules become associated inside micelles, tiny sphere formed by soap molecules with polar hydrophilic (water-attracting) groups on the outside and wrapping a lipophilic (fat-attracting) pocket, which protects the oil/fat molecules from the water making it soluble $[10,11]$. The physicochemical features of soap depend on numerous aspects which may include nature and the strength of alkali as well as type and saponification value of oil used for the preparation of soaps. Therefore, main physiochemical characteristics of the soaps may include TFM, free caustic alkalinity, $\mathrm{pH}$, moisture content, emulsification etc. [12, 13]. In current study, physicochemical properties of toilet and baby soaps were evaluated for their quality. Important quality parameter including $\mathrm{pH}$, moisture content, free caustic alkali, total alkali, TFM, foam height and emulsification tests were performed to check the quality of soaps which are largely utilized.

\section{Materials and Methods Reagents and Sample Collection}

All solvents, chemicals and reagents were used of analytical grade and purchased from E. Merck (Darmstadt, Germany). Eighteen branded soaps including fourteen toilet and four baby soaps were collected from the market of Hyderabad, Pakistan and coded as S-1, S-2, S-3, S-4, S-5, S-6, S-7, S-8, S-9, S-10, S-11, S-12, S-13, S-14 and for baby soap SB-15, SB-16, SB-17 and SB-18. The high-quality of soap selection was based on the higher utilization/demand of these brands in the local market.

\section{Physicochemical Parameters}

All the physicochemical parameters such as moisture content, $\mathrm{pH}$, total fatty matter, free alkali, and total alkali of soap samples were determined by official AOCS method.

\section{Moisture Content}

Moisture content of soap samples were determined using official method of AOCS Db 148 [14]. Around $5 \mathrm{~g}$ soap sample weighed into a tarred moisture dish which was previously dried for 1 hour at $105^{\circ} \mathrm{C} \pm 2$ and cooled to room temperature in a desiccator. After 1 hour heating periods showed a loss of not more than $0.1 \%$ when constant weight is attained successively.

Moisture content $\%=$ loss in weight $\times 100$ / weight of sample.

$p H$

$\mathrm{pH}$ of soap samples was determined using official method of AOCS G 7-56 [14]. About 50 $\mathrm{mL}$ of distilled water added into a $250 \mathrm{~mL}$ beaker and heated to a temperature of 70 to $80{ }^{\circ} \mathrm{C}$. The hot water poured into $50 \mathrm{~g}$ of the soap sample, added few boiling chips. Placed thermometer in the mixture and heated slowly to $95^{\circ} \mathrm{C}$. The solution was stirred with the glass rod till the sample being brought to the specified temperature. When the temperature reached at $95^{\circ} \mathrm{C}$, beaker was removed with its contents from the heat and allowed to stand until phases separate. After this, with the aid of a suitable pipette the aqueous layer drawn off and transferred to a $50 \mathrm{~mL}$ beaker. The $\mathrm{pH}$ was determined to the nearest 0.1 unit on the aqueous solution at $25^{\circ} \mathrm{C}$. 


\section{Total Fatty Matter}

Total fatty matter was estimated via followed previously reported method [15]. Approximately, $10 \mathrm{~g}$ of powdered form of soap was diluted in $150 \mathrm{~mL}$ distilled water and heated. $20 \mathrm{~mL}$ of $15 \% \mathrm{H}_{2} \mathrm{SO}_{4}$ was added in soap solution while heating until obtained a clear solution and left for $30 \mathrm{~min}$. Two separate layers were formed and upper layer of fatty acids floating on surface separated carefully. The layer was allowed to cool to form a cake. The cake was removed, dried and weighed to obtain the total fatty matter using following formula.

$$
\% \mathrm{TFM}=\mathrm{A}-\mathrm{X} \times 100,
$$

where $\mathrm{A}=$ weight of petri dish + sample $\mathrm{W}=$ weight of soap and $\mathrm{X}=$ weight of petri dish

\section{Total Alkali}

About $10 \mathrm{~g}$ of the soap sample was weighed, added $100 \mathrm{~mL}$ of ethanol (96\%) and boiled for $10 \mathrm{~min}$. After that $5 \mathrm{~mL}$ of $1 \mathrm{~N} \mathrm{H}_{2} \mathrm{SO}_{4}$ was added and the resulting mixture allowed boiling until the soap sample dissolved over a period of $5 \mathrm{~min}$. The hot solution was titrated with $1 \mathrm{~N} \mathrm{NaOH}$ till a pink color showed at the end point using phenolphthalein as an indicator. The process was repeated three times [14]. The percentage total free alkali (\%) was calculated as follows:

\% Total alkali $=3.1(\mathrm{Va}-\mathrm{Vb}) / \mathrm{w}$

Where $\mathrm{Va}=$ volume of acid, $\mathrm{Vb}=$ volume of base and $\mathrm{w}=$ weight of sample

\section{Free Alkali}

Free alkali of soap sample was determined by AOCS official method Da 5-44 [14]. About 10 $\mathrm{g}$ of the sample dissolve in $100 \mathrm{~mL}$ freshly boiled distilled water into a $250 \mathrm{~mL}$ beaker. Added $0.5 \mathrm{~N}$ $\mathrm{H} 2 \mathrm{SO} 4$ in measured quantity to make the solution acid. Heated the solution at $60{ }^{\circ} \mathrm{C}$ until the fatty acids separate in a clear layer. Titrated with $0.5 \mathrm{~N} \mathrm{NaOH}$ in the presence of phenolphthalein indicator $(0.5 \mathrm{~mL})$ until the solution is almost neutral. It should remain slightly on the acid side to phenolphthalein. Evaporated to dryness on a steam bath and dissolved in $200 \mathrm{~mL}$ of neutral ethyl alcohol. In the end solution was titrated with $0.5 \mathrm{~N} \mathrm{NaOH}$ to the appearance of a faint pink color.

Free Alkali \% = A-B $\times 2.805$, weight of sample

\section{Foam Height}

For the determination of the foam formation of the soap samples, approximately $10 \mathrm{~g}$ of the soap sample was placed in $1 \mathrm{~L}$ measuring cylinder and added distilled water to make up to the $100 \mathrm{~mL}$ mark. The resulting solution was vigorously shaken 20 times (up and down, with care that it did not spill). The foam height was taken from the $100 \mathrm{~mL}$ mark on the measuring cylinder to the foam height level and recorded as the foam capacity [16].

\section{Emulsification Test}

For the determination of emulsification of soap, approximately $10 \mathrm{~mL}$ of distilled water was poured into a test tube, added $5 \mathrm{~mL}$ of mineral oil and 10 drops of soap solution. The test tube was shaken for 2 minutes and then left to stand. Observed the extent of emulsification and noted as reported earlier [10].

\section{Statistical Analysis}

Two samples of each soap brand were collected and each sample analyzed three times. The data obtained were put into Origin 7 program and reported as the means $(n=2 \times 3 \pm$ standard deviation).

\section{Results and Discussion}

Physicochemical characteristics of commercially available soaps prepared and sold in Pakistani market were evaluated. The present study was conducted to assess the quality of eighteen soap samples. The results of physicochemical examination reflecting the characteristics of the soap and are shown in (Table 1).

\section{Analysis of Moisture Content}

Moisture content is a parameter used in assessing the shelf life of a product. High moisture content in soap would lead to reaction of excess 
water with unsaponified fat to give free fatty acid and glycerol in a process called hydrolysis of soap on storage. The existence of liquid especially water attributes moisture usually in trace extent. The result of moisture content is shown in the (Fig 1). Moisture content in soap samples was found in the range of $5.40-15.12 \%$. The highest moisture content was observed in SB-15 sample and lowest moisture content was observed in S-5. The result obtained in this study for moisture content of some branded soap was lower than the reported studies $9.4 \%-16.9 \%$ [13], $18.8 \%-22.5 \%$ [14], $29.05 \%$ [17] and 9\% - 21\% [18]. Moisture content in some soap samples reported fall within the limits of Encyclopedia of Industries Chemical analysis $(10 \%-15 \%)$. From our experimental results, all soap samples fall within the limits of International Standard (IS). Furthermore, the difference in results may be due to the soap preparing methods.

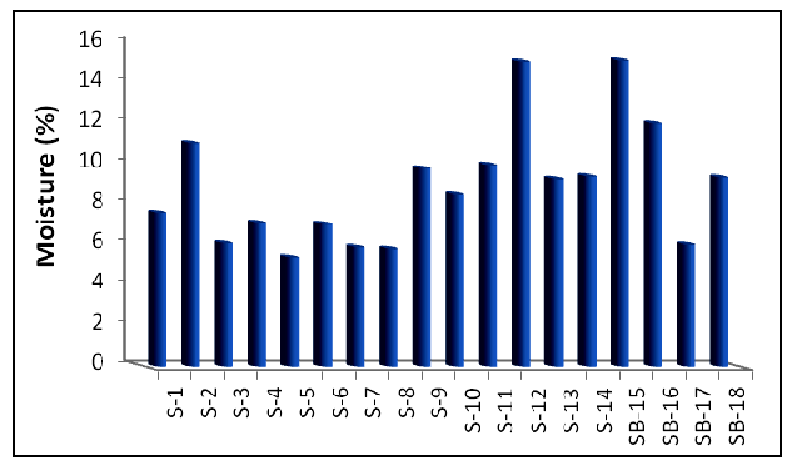

Figure 1. Mean value of moisture content of toilet soap

\section{Analysis of pH}

The $\mathrm{pH}$ in the analyzed samples was found in the range of 7.29-11.53. The result of $\mathrm{pH}$ is shown in the (Fig 2). The $\mathrm{pH}$ results obtained in the current study for soap samples was lower than the reported studies $9-11$ [19] and 10.72 [20] except few samples. The $\mathrm{pH}$ values obtained for $\mathrm{S}$ 4 and S-13 was found to be higher as compared with the results of other reported studies 9 [16],

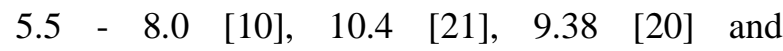
7.84-10.55 [22]. High pH values in soaps are due to the incomplete hydrolysis resulting from saponification process. It can be overcome by adding excess fat or oil to reduce the harshness of soap [20]. The higher values of $\mathrm{pH}$ indicated that analyzed soaps are corrosive to the skin. Generally, soap is alkaline to aqueous solution and these alkaline substances acts as a barrier against bacteria and viruses by neutralize the body's protective acid mantle. Healthy skin has a $\mathrm{pH}$ of 5.4 to 5.9 [21]. S-4 has greater $\mathrm{pH}$ from the recommended values 7-8, on the other hand except samples S-3, S-7, SB-15 and SB-17, rest of the analyzed soap samples were not good for the skin.

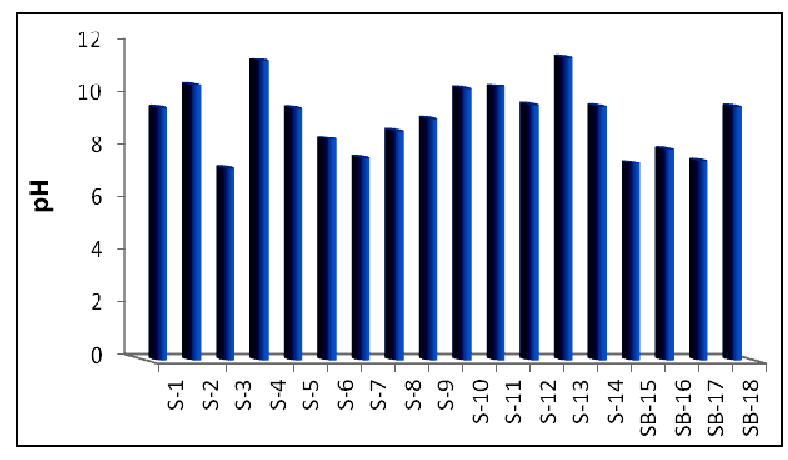

Figure 2. Mean value of $\mathrm{pH}$ in $10 \%$ soap solution

\section{Analysis of Total Fatty Matter}

The TFM results obtained in current study are shown in (Fig 3). The sample S-4 has the lowest value of TFM (59.23\%) and S-3 had highest percentage of TFM $(91.51 \%)$. The results obtained in this study showed that lower TFM was observed in soaps as compared to the reported study $74 \%$ - 92\% [13]. On the other hand, the TFM value for some soap samples were found higher than some previous finding 58\% [20], 59\% [21] $22,67.8-71.8 \%$ [14], 62\% [16] and 66.74\% $82.02 \%$ [15]. Quantities of the used fatty materials are responsible these differences in TFM and perhaps due to the difference in the saponification method. The lower TFM value is due to presence of unreacted $\mathrm{NaOH}$ in the mixture [11]. However, dry skin needs soap which contain higher percentage of TFM content (80\%), which make skin smooth by rehydrating and additionally the high oil content within the soap acts as a lubricant throughout the day [21]. The TFM (\%) by mass is 
the most important factor to be considered in soap quality, higher the TFM content better is the quality. The IS requirement for Grade 1 soap should have $76 \%$ minimum TFM. On the basis of grading sample S- 3, S-5, S-7, S-11, SB-15, SB-16, SB-17 and SB- 18 fall in Grade 1 category soaps.

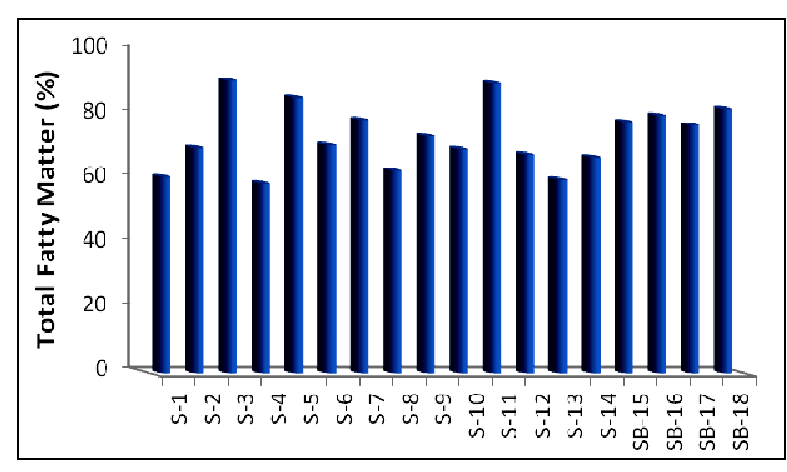

Figure 3. Mean value of total fatty matter in toilet soap

\section{Analysis of Total Alkali}

Total alkaline material present in soap is the total alkalinity. They include alkaline components such as hydroxides, sodium (II) oxide, carbonates and bicarbonates. Fig 4 shows the analyzed results of total alkali of soap samples. Figure indicated that total alkali in soap samples found at $0.13-1.60 \%$. The result observed in current study for some soap samples were higher than the reported studies $0.57 \%$ [23] and $0.24 \%$ [21]. Total alkali \% by mass IS requirement is just $1.5 \%$. All analyzed soap samples were within the limit of recommended except S-1, S-4, S-8 and S-13.

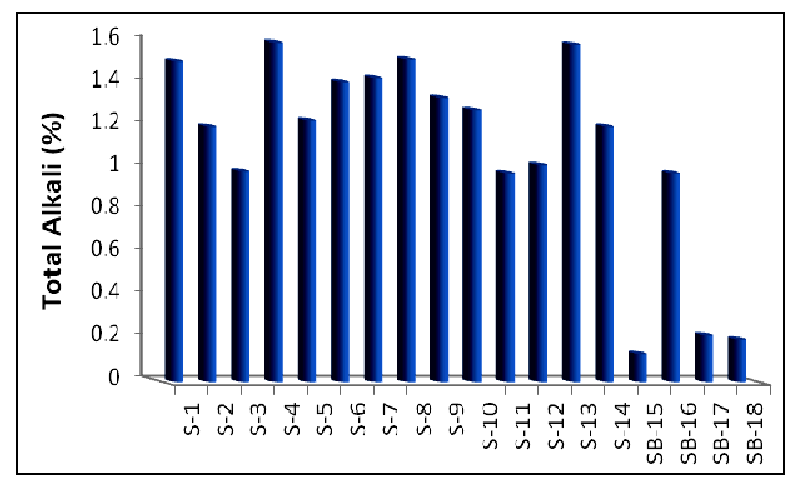

Figure 4. Mean value of total alkali in toilet soap

\section{Analysis of Free Alkali}

One of the most important parameter that determine the abrasiveness of any given soap is free alkali [24]. Table 1 shows the free alkali values of analyzed soap samples. Free alkali in soaps was found in the range between 0.01- 0.62\%. The result obtained in current study for some toilet soaps were higher than the results found in reported studies $\leq 0.1 \%$ [13], $0.002-0.06 \%$ [21], $0.2 \%$ [16] and $0.06 \%-0.09 \%$ [14]. On the other hand, our results of free alkali of some toilet soaps was lower than the toilet soap of some other studies $2.95 \%$ [19] 16 and $1.24 \%$ [26]. From the current analysis, the free alkali for toilet soap samples was found between the limits of recommendation. Free alkali $\%$ by mass IS requirement is just $0.5 \%$. In present study sample S-1 and S- 4 showed higher free alkali than IS requirements.

\section{Foam Height}

Foam test is an important parameter for acceptability of soap standard requirement grade 3:200 mL. In this study foam height in toilet soap was found at $2.3-8.5 \mathrm{~cm}$. The highest value of foam height was observed in sample S-14 and lowest in S-11 as shown in Table 1. The obtained result of foam height was found higher in comparison to the reported studies 1.7 to $5.4 \mathrm{~cm}$ [15] and $1.8 \mathrm{~cm}$ [26]. From the results, it was observed that all toilet soap samples passed lather test (foam height).

\section{Emulsification}

Emulsification was found to be positive in all analyzed soap samples. The findings of emulsification test were compared with other reported studies and found that all of the previous studies reported emulsification in soaps regardless the concentration and type of oil used in the preparation of soaps [27-29]. The consolidated results of physiochemical properties of analyzed soap samples are shown in Table 1. 
Table 1. Physicochemical properties of important parameters of soaps $(\mathrm{n}=3)$.

\begin{tabular}{|c|c|c|c|c|c|c|c|}
\hline Sample & $\begin{array}{c}\text { Moisture } \\
\text { Content }(\%)\end{array}$ & $\begin{array}{l}\text { pH } 10 \% \text { in } \\
\text { solution }\end{array}$ & $\begin{array}{c}\text { TFM Value } \\
(\%)\end{array}$ & $\begin{array}{c}\text { Total } \\
\text { Alkali }(\%)\end{array}$ & $\begin{array}{l}\text { Free Alkali } \\
(\%)\end{array}$ & $\begin{array}{c}\text { Foam Test } \\
(\mathrm{cm})\end{array}$ & Emulsification \\
\hline S-1 & $7.16 \pm 0.05$ & $9.62 \pm 0.04$ & $61.0 \pm 0.03$ & $1.51 \pm 0.02$ & $0.61 \pm 0.09$ & $7.30 \pm 0.3$ & + \\
\hline S-2 & $11.05 \pm 0.08$ & $10.49 \pm 0.06$ & $70.12 \pm 0.02$ & $1.20 \pm 0.03$ & $0.08 \pm 0.03$ & $7.00 \pm 0.02$ & + \\
\hline S-3 & $6.1 \pm 0.03$ & $7.29 \pm 0.01$ & $91.00 \pm 0.06$ & $0.99 \pm 0.03$ & $0.01 \pm 0.01$ & $7.80 \pm 0.06$ & + \\
\hline S-4 & $7.12 \pm 0.05$ & $11.39 \pm 0.04$ & $59.00 \pm 0.01$ & $1.60 \pm 0.05$ & $0.62 \pm 0.09$ & $7.50 \pm 0.05$ & + \\
\hline$S-5$ & $5.40 \pm 0.03$ & $9.60 \pm 0.03$ & $85.68 \pm 0.03$ & $1.23 \pm 0.04$ & $0.07 \pm 0.02$ & $7.50 \pm 0.05$ & + \\
\hline S-6 & $7.05 \pm 0.08$ & $8.42 \pm 0.03$ & $71.00 \pm 0.04$ & $1.41 \pm 0.01$ & $0.14 \pm 0.02$ & $6.90 \pm 0.01$ & + \\
\hline S-7 & $5.90 \pm 0.04$ & $7.71 \pm 0.03$ & $78.84 \pm 0.04$ & $1.43 \pm 0.01$ & $0.10 \pm 0.01$ & $7.80 \pm 0.02$ & + \\
\hline$S-8$ & $5.82 \pm 0.05$ & $8.73 \pm 0.02$ & $62.94 \pm 0.02$ & $1.52 \pm 0.02$ & $0.02 \pm 0.05$ & $8.50 \pm 0.04$ & + \\
\hline S-9 & $9.80 \pm 0.06$ & $9.171 \pm 0.01$ & $73.68 \pm 0.04$ & $1.34 \pm 0.03$ & $0.08 \pm 0.01$ & $7.10 \pm 0.03$ & + \\
\hline$S-10$ & $8.52 \pm 0.05$ & $10.32 \pm 0.04$ & $69.72 \pm 0.03$ & $1.28 \pm 0.04$ & $0.05 \pm 0.08$ & $7.00 \pm 0.02$ & + \\
\hline$S-11$ & $9.98 \pm 0.06$ & $10.41 \pm 0.03$ & $90.02 \pm 0.06$ & $0.98 \pm 0.01$ & $0.02 \pm 0.01$ & $2.30 \pm 0.01$ & + \\
\hline$S-12$ & $15.06 \pm 0.04$ & $9.73 \pm 0.03$ & $68.06 \pm 0.05$ & $1.02 \pm 0.01$ & $0.06 \pm 0.03$ & $6.30 \pm 0.04$ & + \\
\hline S-13 & $9.26 \pm 0.01$ & $11.53 \pm 0.09$ & $60.12 \pm 0.04$ & $1.59 \pm 0.09$ & $0.13 \pm 0.01$ & $8.70 \pm 0.03$ & + \\
\hline S-14 & $9.39 \pm 0.03$ & $9.67 \pm 0.01$ & $67.16 \pm 0.05$ & $1.20 \pm 0.01$ & $0.09 \pm 0.02$ & $8.90 \pm 0.05$ & + \\
\hline SB-15 & $15.12 \pm 0.03$ & $7.5 \pm 0.05$ & $78.13 \pm 0.01$ & $0.13 \pm 0.03$ & $0.03 \pm 0.05$ & $5.2 \pm 0.08$ & + \\
\hline SB-16 & $12.01 \pm 0.01$ & $8.02 \pm 0.03$ & $80.21 \pm 0.09$ & $0.98 \pm 0.01$ & $0.04 \pm 0.02$ & $6.4 \pm 0.01$ & + \\
\hline SB-17 & $6.03 \pm 0.09$ & $7.6 \pm 0.04$ & $77.12 \pm 0.03$ & $0.22 \pm 0.08$ & $0.01 \pm 0.01$ & $7.5 \pm 0.09$ & + \\
\hline SB-18 & $9.34 \pm 0.06$ & $9.66 \pm 0.01$ & $82.23 \pm 0.01$ & $0.20 \pm 0.05$ & $0.02 \pm 0.01$ & $8.2 \pm 0.06$ & + \\
\hline
\end{tabular}

\section{Conclusion}

In this study, physiochemical properties of eighteen soap samples were evaluated using standard methods. The results of the present study indicated that samples S- 3, S-5, S-7, S-11, S-15, S-16, S-17 and S-18 were fall in Grade 1 category of soaps. Foam test is an important parameter for acceptability of soap and all brands passed lather test. It is essential to select soap that strikes a balance among the physicochemical parameters. The physiochemical properties of soap revealed that most of the test parameters were within the recommended IS limits except $\mathrm{pH}$ and total alkali of few soap samples.

\section{References}

1. G. Baltas and P. C. Argouslidis, Int. J. Retail Distrb. Manag., 35 (2007) 328. https://doi.org/10.1108/095905507107437 $\underline{08}$

2. P. Oghome, M. U. Eke and C. I. Kamalu, Int. J. Mod. Eng. Res., 2 (2012) 2930. https://doi.org/10.1080/0972060X.2014.9740 $\underline{78}$
3. D. Amponsah, G. E Sebiawu, and H. Nagai, Int. J. Adv. Res. Technol., 3 (2014) ISSN 2278.

http://www.ijoart.org/docs/Quality-Analysisof-selected-Liquid-Soaps-in-Ghana.pdf

4. N. O. Sawyerr, P. A. Danquah and A. Benson, Afr. J. Appl. Res., 3 (2017) 38. http://www.ajaronline.com/index.php/AJAR/ article/view/197

5. S. M. Oluwatoyin, J. Microbiol. Biotech. Res., 1 (2017) 29

https://jmbronline.com/index.php/JMBR/arti cle/view/4

6. F. Rais, R. Baati, N. Damak, A. Kamoun and M. Chaabouni, J. Am. Oil Chem. Soc., 85 (2008) 869. https://doi.org/10.1007/s11746-008-1266-2

7. A. Alizadeh, M. Balali-Mood, A. Mahdizadeh and B. Zanjani, Iran. J. Toxicol., 11 (2017) 1. http://ijt.arakmu.ac.ir/article-1-598-en.html

8. D. J. Anneken, S. Both, R. Christph, G. Fieg, U. Steinberner and A. Westfechtel, Ullmann's Encyclopedia of Industrial Chemistry, (2006) 
https://doi.org/10.1002/14356007.a10_245.p $\underline{\mathrm{ub} 2}$

9. T. P. Joshi, Int. J. Appl. Chem., 13 (2017) 283.

http://www.ripublication.com/ijac17/ijacv13 n2_10.pdf

10. V. Popescu, A. Soceanu, S. Dobrinas, G. Stanciu, and D. T. Epure, Sci. Study Res. Chem. Chem. Eng., 12 (2011) 257. https://core.ac.uk/download/pdf/26208750.pd f

11. R. O. I. A. Awang, S. A. L. M. I. A. H. Ahmad and R. A. Z. M. A. H. Ghazali, J. Oil Palm Res., 13 (2001) 33.

http://jopr.mpob.gov.my/wp-

content/uploads/2013/09/joprv12dec2001roila1.pdf

12. A. Y. Girgis, Grasas y Aceites, 50 (1999) 185.

https://doi.org/10.3989/gya.1999.v50.i3.654

13. A. Kuntom, H. Kifli and P. K. Lim, J. Am. Oil Chem. Soc., 73 (1996) 105. https://doi.org/10.1007/BF02523455

14. C. N. Osuji, T. O. Akunna, and E. O. Ahaotu, Int. J. Appl. Sci. Eng., 1 (2013) 73. http://www.ijapscengr.com/pdffiles/Volume-1-no-2-2013/73-78.pdf

15. U. Eke, O. Dosumu, E. Oladipo and F. Agunbiade, Niger. J. Sci., 38 (2004) 19. http://www.unilorin.edu.ng/UIL/165.pdf

16. C. Beetseh and M. Anza, Afr. J. Biotechnol., 3 (2013) 82.

17. H. Ogunsuyi and C. Akinnawo, J. Appl. Sci. Environ. Mgmt., 16 (2012) 363.

https://www.ajol.info/index.php/jasem/article /view/90988

18. S. K. Ashrafy Habib, M. S. Sorowar, J. Karmoker, M. K. Khatun and S. M. Al-Reza, Int. J. Adv. Res. Chem. Sci., (IJARCS) 3 (2016) 9.

http://dx.doi.org/10.20431/2349$\underline{0403.0306002}$

19. A. Oyedele, Niger. J. Nat. Prod. Med., 6 (2002) 26. http://dx.doi.org/10.4314/njnpm.v6i1.11687
20. A. Warra, I. Wawata, S. Gunu and F. Atiku, Adv. Appl. Sci. Res., 2 (2011) 617 http://www.imedpub.com/abstract/soappreparation-from-soxhlet-extracted-nigeriancotton-seed-oil-16304.html

21. E. Mak-Mensah and C. Firempong, Asian J. Plant Sci. Res., 1 (2011) 1. https://pdfs.semanticscholar.org/7d12/b2e18e 0d1dd020c16658b38b093c6cc3a7c5.pdf

22. Y. Tan, S. Ong, K. Berger, H. Oon and B. Poh, J. Am. Oil Chem. Soc., 62 (1985) 999. https://doi.org/10.1007/BF02935701

23. M. D. Guillen and N. Cabo, J. Sci. Food Agric., 75 (1997) 1.

https://doi.org/10.1002/(SICI)10970010(199709)75:1<1::AIDJSFA842>3.0.CO;2-R

24. C. Onyekwere, B. Eng. Thesis, (1996) 1.

25. B. R. Mendes, D. M. Shimabukuro, M. Uber and K. T. Abagge, J. Pediatr., 92 (2016) 290. https://doi.org/10.1016/j.jped.2015.08.009

26. A. Warra, Afr. J. Pure Appl. Chem., 7 (2013) 139.

https://doi.org/10.5897/AJPAC11.016

27. M. Shahin, S. A. Hady, M. Hammad and N. Mortada, Int. J. Pharm. Stud. Res., 2 (2011) 45.

http://www.technicaljournalsonline.com/ijpsr /VOL\%20II/IJPSR\%20VOL\%20II\%20ISSU E\%20II\%20APRIL\%20JUNE\%202011/Arti cle\%207\%20IJPSR\%20VOL\%20II\%20ISSU E\%20II.pdf

28. W. R. Sutterlin, N. Killingsworth, C. Blanchard, L. Ryan and C. T. Check, Complete saponification and acdulation of natural oil processing by products. United States Patent, US 9, 546, 342 B1, (2017). https://patentimages.storage.googleapis.com/ b1/bc/5d/3985d07182e1bf/US9546342.pdf

29. R. Chanamai and D. J. McClements, Colloids Surf. A, 172 (200) 79. https://doi.org/10.1016/S09277757(00)00551-3 